\title{
ASN Berinovasi dalam Menghadapi Refocusing Anggaran Di Masa Pandemi Covid 19
}

\author{
Innovating ASN in Facing Covid -19 \\ Budget Refocusing \\ Ray Septianis Kartika \\ Badan Penelitian dan Pengembangan Kemendagri \\ Jl. Kramat Raya No. 132 Jakarta Pusat, Indonesia \\ Telp: (021) 3101953, 3101955 \\ Email: raseka1979@gmail.com
}

(Diterima 17/05/21; Disetujui 20/09/21)

\begin{abstract}
Innovating in work is a solution to solving budget refocusing problems. The budget is indeed an indicator of the implementation of the budget and the implementation of an accountable program. However, for now, the ASN data server can work optimally because budget constraints are a challenge to provide quality output. On a macro level, ASN was a positive disaster for budget re-arrangement. This is because refocusing is a diversion in overcoming a pandemic. This study becomes a means of proving that ASN can work without budget support that is able to achieve maximum performance. The purpose of this study is to see how the performance of ASN in facing budget rearrangement. The method is descriptive qualitative with respondents from the central government and local governments recorded on the eyeglass application form. The results of the study are analyzed that first, refocusing the budget does not affect ASN in its work. Second, innovating ASN is directed at work coaching without reducing target institutions and target individuals. Third, creating work innovation with a research revolution through technology support so that it does not rely on budget for work. All of them are concrete forms of ASN in developing competence and enthusiasm for work. Without a problem with refocusing, but displaying the maximum result or output has become an objective concrete step.
\end{abstract}

\section{Keyword: ASN, Innovation, Budget Refocusing}

\begin{abstract}
Abstrak
Berinovasi dalam bekerja merupakan solusi untuk mengatasi permasalahan refocusing anggaran. Anggaran memang menjadi indikator terlaksananya penyerapan anggaran dan terlaksananya program secara akuntabel. Akan tetapi untuk saat ini, tuntutan ASN dapat maksimal bekerja di tengah keterbatasan anggaran menjadi tantangan untuk dapat memberikan output yang berkualitas. Secara makro, ASN menanggapi positif terhadap refocusing anggaran. Dikarenakan refocusing merupakan pengalihan dalam mengatasi masa pandemi. Kajian ini menjadi ajang pembuktian bahwa ASN dapat bekerja tanpa dukungan anggaran mampu berkontribusi mencapai kinerja yang maksimal. Tujuan kajian ini adalah untuk mengetahui kinerja ASN dalam menghadapi refocusing anggaran. Metodenya menggunakan deskriptif kualitatif dengan respondennya berasal dari unsur pemerintah pusat dan pemerintah daerah yang terekam dalam aplikasi Google Form. Hasil dari kajian teranalisa bahwa pertama, refocusing anggaran tidak mempengaruhi ASN dalam berkerja. Kedua, ASN berinovasi diarahkan untuk mengatur pola kerja dengan tidak mengurangi capaian target lembaga maupun target individu. Ketiga, menciptakan inovasi kerja dengan revolusi riset melalui dukungan teknologi sehingga tidak mengandalkan anggaran dalam bekerja. Kesemuanya adalah bentuk nyata ASN dalam mengembangkan kompetensi dan semangat untuk bekerja. Tanpa
\end{abstract}


mempermasalahkan refocusing, tetapi menampilkan hasil atau output kerja yang maksimal sudah menjadi langkah kongkrit yang objektif.

Kata Kunci : ASN, Inovasi, Refocusing Anggaran

\section{PENDAHULUAN}

Tahun ini berbeda dari tahun-tahun sebelumnya, masa pandemi mengharuskan struktur anggaran pemerintah pusat maupun daerah diprioritaskan penggunaannya untuk penanganan pandemi COVID-19 seperti belanja kesehatan, jaring pengaman sosial, dan pemulihan perekonomian. Peralihan strukturisasi anggaran untuk menangani permasalahan tersebut, tidak lagi wacana tetapi implementasi yang sudah dilakukan pemerintah pusat maupun daerah. Refocusing menjadi sebuah diskusi yang menarik, ketika Aparatur Sipil Negara (ASN) sebagai pelayan masyarakat menjadi salah satu yang terkena dampaknya. Mengapa dikatakan demikian, mengingat ASN sebagai abdi negara bekerja berdasarkan anggaran yang telah tertuang dalam APBN/APBD. Permasalahannya dengan adanya pemotongan anggaran, ASN selaku pelaksana kegiatan akan mulai memutar balik untuk mengoperasionalkan kegiatan/program tanpa adanya dukungan anggaran. Terutama pengaruh yang sangat besar terhadap laporan harian yang disampaikan ASN kepada pimpinan serta pencapaian target program. Selain itu, untuk anggaran belanja TKDD, pemerintah telah menentukan bahwa anggaran dana desa dapat digunakan sebagai dana jaring pengaman sosial di desa berupa bantuan langsung tunai kepada penduduk miskin di desa dan kegiatan penanganan wabah COVID-19 (Kemenkeu, 2020). Artinya, penggunaan dana desa tersebut bisa menjadi pertimbangan untuk mengalokasikan realisasi program yang sudah direncanakan, tentunya dengan memperhitungkan nilai kebermanfaatannya.

Pada dasarnya, realisasi program yang dilakukan ASN dapat menciptakan inovasi yang akurat. Menciptakan inovasi yang mampu mendukung pencapaian target/program sekaligus membentuk ASN yang dapat berpikir kreatif untuk mengatasi krisis anggaran yang dialami pada masa pandemi. Seperti kita ketahui, pemangkasan anggaran untuk kegiatan non prioritas adalah mutlak dan menjadi sebuah keharusan. Bahkan pemotongan anggaran besar-besaran tidak menyurutkan kinerja ASN dalam menjalankan perannya. Lebih lanjut Taher (2020) mengungkapkan refocusing anggaran sesuai dengan Intruksi Presiden agar memotong Anggaran Pendapatan dan Belanja Negara (APBN) dan Anggaran Pendapatan dan Belanja Daerah (APBD) yang tidak prioritas. Diperkuat pernyataan Elena (2020) bahwa seluruh kementerian/lembaga dan kepala daerah agar tetap transparan dan akuntabel dalam penanganan pandemi Covid-19, baik di bidang kesehatan maupun ekonomi. Artinya bahwa pemerintah dan pemerintah daerah bersama-sama mewujudkan pelayanan masyarakat. Dengan tidak mengurangi target/program namun tetap berjalan dengan segala keterbatasan anggaran.

Tindakan bersama tersebut sudah senyatanya dilakukan, pemangkasan anggaran untuk kegiatan rapat dan perjalanan dinas dirasakan menguras anggaran yang terbilang besar. ASN dapat menciptakan peluang yang tepat supaya ASN secara bijaksana mengelola dan memanfaatkan anggaran yang minimalis untuk meningkatkan kinerjanya. Kreativitas ASN dibutuhkan agar mampu memanfaatkan peluang tanpa mengandalkan kegiatan yang bersumber dari APBN/APBD. Seperti hasil kajian Yanida (2013), semakin besar tingkat partisipasi pegawai dalam penyusunan anggaran maka kinerja pegawai juga akan meningkat. Begitupula kajian Husin (2010) menemukan bahwa partisipasi anggaran memiliki hubungan positif dengan kinerja aparatur pemerintah. Artinya bahwa kinerja ASN dipengaruhi oleh penyediaan anggaran yang ada. Hasil riset tersebut juga tidak bisa diterima $100 \%$, harus dilakukan riset kembali untuk melihat kebenarannya. 
Seperti masa pandemi Covid 19, ASN melakukan aktivitas work from home, yaitu melakukan pekerjaan untuk meningkatkan kinerjanya dari rumah. Terlepas dari penggunaan APBN/APBD, faktanya ASN dapat berkarya, produktif, dan mencari peluang untuk mendukung kemampuannya (Helmy, 2020). Diperkuat kajian Jaenudin (2015) yang menegaskan faktor yang mempengaruhi kinerja PNS yaitu pendidikan dan pelatihan, disiplin kerja, motivasi kerja, dan kemampuan SDM. Begitupula hasil kajian Londong (2015) menyatakan bahwa faktor yang mempengaruhi kinerja PNS didasarkan atas pelatihan, motivasi kerja, dan distribusi pekerjaan. Pada pelatihan, salah satu tujuannya adalah untuk memperbaiki kinerja, sedangkan motivasi lebih dikaitkan dengan terpenuhinya kebutuhan dan kepuasan pegawai. Distribusi pekerjaan mengarah kepada kepercayaan organisasi terhadap talenta pegawai. Semakin dibebankan dengan tugas, semakin tinggi organisasi mengakui outcome si pegawai. Oleh karenanya perbedaan mendasar dengan kajian terdahulu tertumpu pada: (1) akar permasalahan yang diangkat, (2) sampel dilakukan dengan melibatkan ASN yang berada di pusat maupun daerah, (3) validitas sampel bisa dikategorikan besar, artinya kevalidan data dapat dipertanggungjawabkan.

Oleh karenanya menghadapi problematika refocusing anggaran, setidaknya ASN menerapkan inovasi dalam pola kerjanya. Tentunya dengan berinovasi dalam mengatur irama kerja agar tidak menghilangkan produktivitas kerja ASN. Inovasi menjadi tuntutan agar ASN tetap produktif, kreatif, dan tidak mengalami hambatan dalam berkarya. Sebagaimana yang diungkapkan Jalis (2018) seorang ASN harus kreatif berinovasi pada setiap pekerjaan dan berkontribusi aktif dalam memecahkan masalah di masa depan. Maknanya adalah inovasi menjadi kunci untuk menjadikan ASN dapat keluar dari permasalahan. Seperti permasalahan yang dihadapi saat ini, yaitu bekerja tanpa dukungan anggaran, refocusing tidak menjadi alasan bagi ASN untuk berdiam diri.

Perumusan masalah kajian ini adalah bagaimana kinerja ASN dalam menghadapi refocusing anggaran? Tujuan kajian adalah untuk menganalisa kinerja ASN dalam menghadapi refocusing anggaran.

\section{TINJAUAN TEORITIS DAN PENELITIAN SEBELUMNYA}

Dalam implementasinya, kinerja ASN memang tidak luput dari penggunaan anggaran. Skema kinerja ASN berubah tidak hanya mengerjakan administratif, tetapi lebih ke hasil. Seperti yang dikatakan Rika (2019) para aparatur sipil negara (ASN) di semua instansi pemerintah mengubah orientasi kerja, dari yang sebelumnya berorientasi prosedur kini pada hasil. Kinerja ASN memang terhalang oleh keterbatasan anggaran yang tersedia, para ASN mulai dari Pejabat Pimpinan Tinggi (PPT) sampai dengan staf, dituntut untuk melakukan kreativitas dan inovasi dalam menjalankan birokrasi di masa pandemi. Anggaran memang dikurangi, namun kreativitas dan inovasi tidak dapat dihalangi. Inilah yang menjadi tantangan bagi ASN untuk tetap berkarya di balik keterbatasan anggaran.

Puspasari (2020) menegaskan kriteria pemangkasan APBD sebagai berikut. Pertama, rasionalisasi belanja barang/jasa dan belanja modal masing-masing minimal sebesar 50\%, serta adanya rasionalisasi belanja pegawai dan belanja lainnya dengan memperhitungkan perkiraan penurunan pendapatan daerah. Kedua, adanya upaya Pemda untuk melakukan rasionalisasi belanja daerah dengan memperhatikan. Ketiga, kemampuan keuangan daerah dengan memberikan toleransi total rasionalisasi belanja barang/jasa dan belanja modal sekurang-kuranganya 35\%. Keempat, penurunan Pendapatan Asli Daerah yang ekstrim sebagai dampak dari menurunnya aktivitas masyarakat dan perekonomian. Kelima, perkembangan tingkat pandemi Covid-19 di masing-masing daerah yang perlu segera mendapatkan penanganan dengan anggaran yang memadai. Keenam, penggunaan hasil rasionalisasi belanja daerah untuk dialokasikan bagi pencegahan/penanganan Covid-19, jaring pengaman sosial, dan menggerakkan/memulihkan perekonomian di daerah. 


\section{METODE}

Kajian ini menggunakan metode deskriptif kualitatif dengan mendeskripsikan latar belakang pemangkasan APBN/APBD dan kinerja ASN setelah adanya pemangkasan APBN/APBD. Kajian cepat ini dilakukan pada Mei 2020 ketika work from home berjalan. Populasinya adalah OPD yang berada di kabupaten, kota, provinsi, dan pemerintah pusat, dalam hal ini Litbang Kemendagri. Dari penyebaran Google Form didapat responden sebanyak 124 orang dengan random secara acak yang terdiri dari ASN yang berada di Kementerian Dalam Negeri (Badan Penelitian dan Pengembangan Kemendagri, Pusat Data dan Informasi, Biro Kepegawaian Setjen, Inspektorat Jenderal, Direktorat Bina Pembangunan Daerah, BPSDM, Dukcapil), Kementerian Perhubungan, Lembaga Ilmu Pengetahuan Indonesia, Badan Kependudukan dan Keluarga Berencana Nasional (BKKBN) serta OPD terkait yaitu Provinsi DKI Jakarta (Bagian Perekonomian Setko Jaksel), Provinsi Jawa Timur (Balitbang), Provinsi DIY (Bappeda), Provinsi Sumatera Selatan (Litbangda), Provinsi Kalimantan Barat (Balitbang), Provinsi Lampung (Balitbang), Provinsi Kalimantan Selatan (Balitbangda), Provinsi Papua (Bappeda), Provinsi Kalimantan Tengah (Badan Penanggulangan Bencana dan Pemadam Kebakaran), Provinsi Sumatera Barat (Balitbang), Provinsi Sulawesi Tengah (Balai Bahasa), Kabupaten Belu (Badan Perencanaan Pembangunan, Penelitian dan Pengembangan Daerah), Kabupaten Banggai (Bappeda Litbang, Setda, Bagian Organisasi), Kabupaten Sidoarjo (Bagian Organisasi, BPKAD, BKD, Inspektorat Daerah, Dinas Perhubungan, DPMPTSP, RSUD, Kecamatan Tangulangin, Kecamatan Waru, Kecamatan Gedangan, Kecamatan Taman, Badan Pelayanan Pajak Daerah, Dinas Permukiman Citra Karya dan Tata Ruang, Dinas Pendidikan dan Kebudayaan, DPMD, Bagian Pemerintahan, Dinas Pemberdayaan Perempuan dan Masyarakat) Kota Malang (Bappeda), Kabupaten Ngawi (Bappelitbang), Kabupaten Kotawaringin Barat (BPKAD), Kabupaten Kulon Progo (Bappeda), Kabupaten Katingan (Bappelitbang), Kabupaten Cirebon (Bappelitbangda), Kabupaten Lamandau (Bappeda), Kota Palopo (Dinas Transmigrasi), Kotawaringin Timur (Bappeda), dan Kota Palangkaraya (Bapedalitbang).

Teknik analisa data dilakukan dengan analisa statistik metode pie chart. Metode ini akan mengembangkan persepsi responden yang akan dikembangkan dengan prosentase pada setiap tanggapan dari responden.

\section{HASIL DAN PEMBAHASAN}

Reformasi birokrasi diarahkan pada upaya melakukan pembaharuan dan perubahan mendasar terhadap sistem penyelenggaraan yang menyangkut aspek kelembagaan, ketatalaksanaan, dan sumber daya manusia aparatur. Dengan kata lain reformasi birokrasi adalah langkah strategis untuk membangun aparatur negara agar lebih berdaya guna dan berhasil guna dalam mengemban tugas umum pemerintahan (Kemenpan, 2009). Caranya adalah dengan melalui peningkatan kualitas kinerja aparatur, yang dicapai baik itu ASN di pusat maupun daerah.

Pada dasarnya kinerja ASN setiap tahunnya selalu dilakukan evaluasi kinerja sesuai dengan UU No 5 tahun 2014 tentang ASN, PP No. 30 Tahun 2019 tentang penilaian kinerja Pegawai Negeri Sipil, dan PP No. 46 Tahun 2011 Tentang Penilaian Prestasi Kinerja PNS. Indikator yang dilakukan untuk penilaian kinerja PNS yaitu hasil kerja yang dicapai pada unit kerja sesuai Sasaran Kinerja Pegawai (SKP) dan Perilaku Kerja. Pada penilaian dilakukan berdasarkan perencanaan kinerja pada tingkat individu dan tingkat unit atau organisasi dengan memperhatikan target, capaian hasil, capaian manfaat, serta perilaku PNS. Kedua aspek penilaian tersebut mutlak dicapai oleh para ASN. 
Akan tetapi, tahun ini tidaklah mudah. ASN dihadapkan pada tantangan untuk meningkatkan kinerja di tengah wabah Covid-19. Tantangan terberatnya bekerja maksimal dengan minimnya dukungan anggaran. Keterbatasan anggaran menjadikan ASN dituntut untuk bekerja sesuai dengan target. ASN harus memiliki strategi untuk menuntaskan program/kegiatan meskipun dukungan anggaran terbatas. Disinilah dituntut ASN yang kreatif dan proaktif dalam memberikan keunggulan kompetensi serta profesionalisme dalam menyelesaikan tugas. Seperti dikatakan Effendi (2008) bahwa reformasi perlu ditopang oleh motivasi untuk mencari cara yang lebih efektif dan efisien.

Tak hanya itu, kinerja ASN akan semakin baik apabila memiliki semangat kerja, budaya, dan etos kerja serta motivasi diri yang tinggi, sebagaimana yang dikemukakan oleh Megasari (2018). Artinya bahwa kinerja ASN sepatutnya tidak berpengaruh terhadap keterbatasan anggaran. Peluang untuk mencapai target dapat dilakukan dengan berbagai cara. Misalnya dengan menerapkan pola kerja yang sistematis dan pragmatis, ataukah dengan cara menciptakan inovasi kerja yang dapat berpengaruh terhadap hasil kerja. ASN yang dapat mencari peluang adalah ASN yang secara alami telah memiliki strategi untuk memanfaatkan potensi dan mengeskplorasi kompetensi sebagai cara menciptakan pola kerja untuk mencapai target. Kian (2015) menjelaskan ada korelasi antara faktor motivasi dan inovasi sehingga menjadi peluang bagi pegawai yang akan berpartisipasi. Lebih lanjut dijelaskan bahwa motivasi eksternal memiliki pengaruh positif dan signifikan terhadap kinerja. Pemberian motivasi yang tepat akan meningkatkan kinerja karyawan dalam melakukan suatu pekerjaannya, sebagaimana hasil kajian Lao (2018: 9).

Sebelum kajian disusun, penulis telah melakukan survei yang dilakukan secara online melalui Google Form. Dari usia, responden memiliki perbedaan usia yang sangat besar. Responden berusia 20 tahun-30 tahun sebanyak 19 orang atau 15,3\%, 31 tahun-41 tahun sebanyak 51 orang atau $41,1 \%$ dan berusia 41 tahun ke atas sebanyak 54 orang atau 43,6 \%. Mayoritas responden berusia 41 tahun $\mathrm{k}$ eatas, sebagai salah satu konsekuensi dalam pemilihan sampel secara acak. Responden dengan tingkat kematangan dalam berpikir dan berpendapat memberikan nilai representasi yang dapat mewakili pendapat responden yang lainnya.

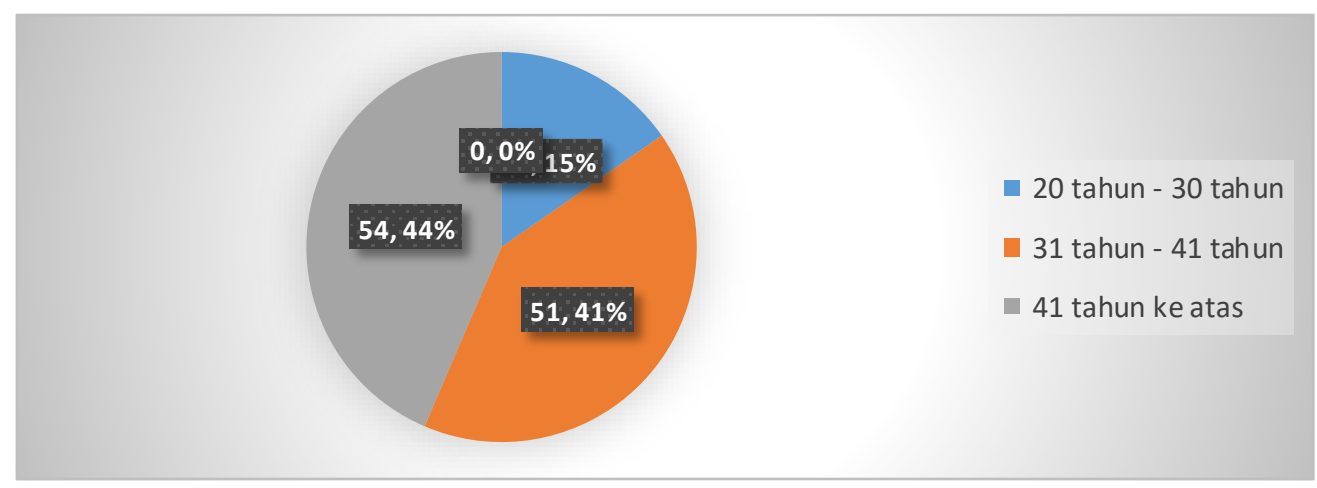

\section{Gambar 1. Usia Responden}

Klasifikasi menurut jabatan responden diketahui setara eselon 2 sebanyak 7 orang $(5,6 \%)$, setara eselon 3 sebanyak 41 orang $(33,1)$, setara eselon 4 sebanyak 57 orang (46 $\%)$, staf sebanyak 19 (15,3\%). Sistem acak ini menjadi pedoman untuk melihat jenjang jabatan yang dimiliki responden. 


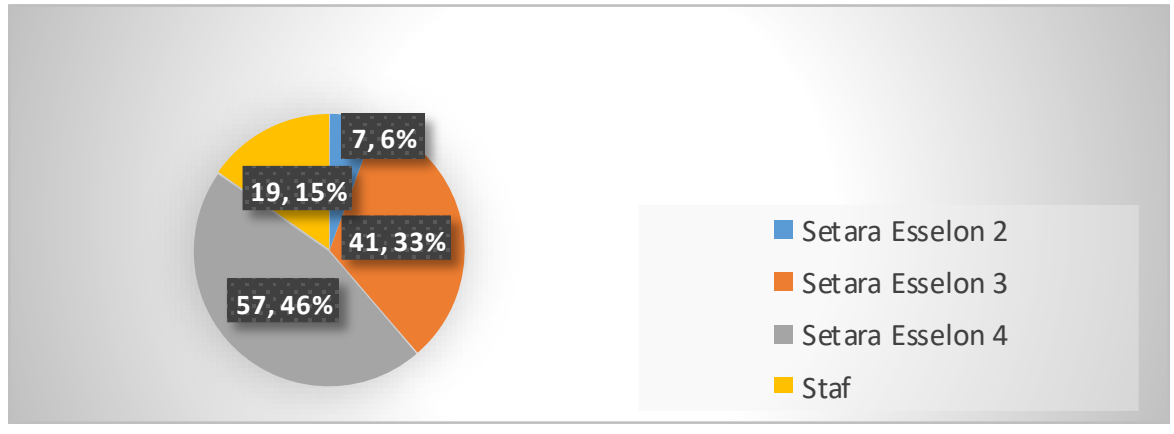

\section{Gambar 2. Jabatan Responden}

Klasifikasi menurut pendidikan, besarannya yaitu S2 sebanyak 61 orang $(49,1 \%)$, S3 sebanyak 11 orang atau (8,9\%), S1 sebanyak 52 orang (42\%). Secara proporsional responden mayoritas berpendidikan S2 yang terbanyak lalu diikuti dengan pendidikan S1 berjumlah 52 orang. Hal ini berarti kevalidan data untuk pemilihan responden dapat dipertanggungjawabkan, dengan melihat pendidikan formal yang dimiliki responden.

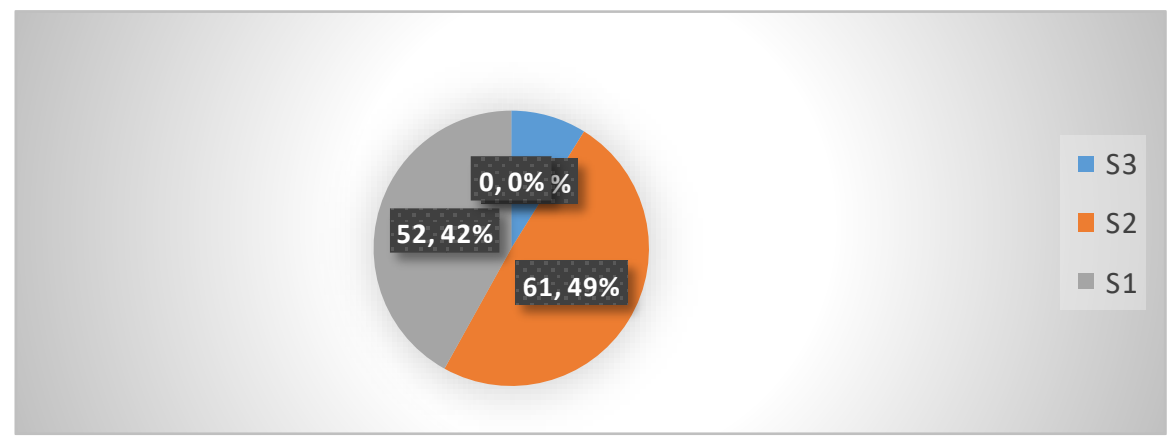

\section{Gambar 3. Pendidikan Responden}

Klasifikasi menurut golongan III/a-III/d sebanyak 82 orang $(66,1 \%)$, golongan IV/a-IV/e sebanyak 42 orang atau (33,9 \%). Secara proporsional, golongan III/a-III/d menjadi responden yang lebih mengingat responden bercampur mulai dari staf sampai dengan kepala bagian.

Berdasarkan hasil survei diketahui motivasi para ASN untuk bekerja terbagi berdasarkan mayoritas, di antaranya: (1) untuk mengabdi pada negara, (2) mencari khazanah pengetahuan, (3) mencari penghasilan, dan (4) beribadah. Argumen ini menjadi sebuah pembuktian bahwa anggaran tidak mempengaruhi kinerja ASN dalam bekerja. Kajian Sutrischastini (2015: 136) menekankan bahwa ada pengaruh positif antara motivasi kerja terhadap kinerja pegawai. Sama halnya kajian Rahsel (2016: 219) menyatakan motivasi kerja mempunyai pengaruh yang signifikan terhadap kinerja pegawai. Maknanya bahwa motivasi menjadi syarat untuk ASN dapat meningkatkan kinerjanya. 


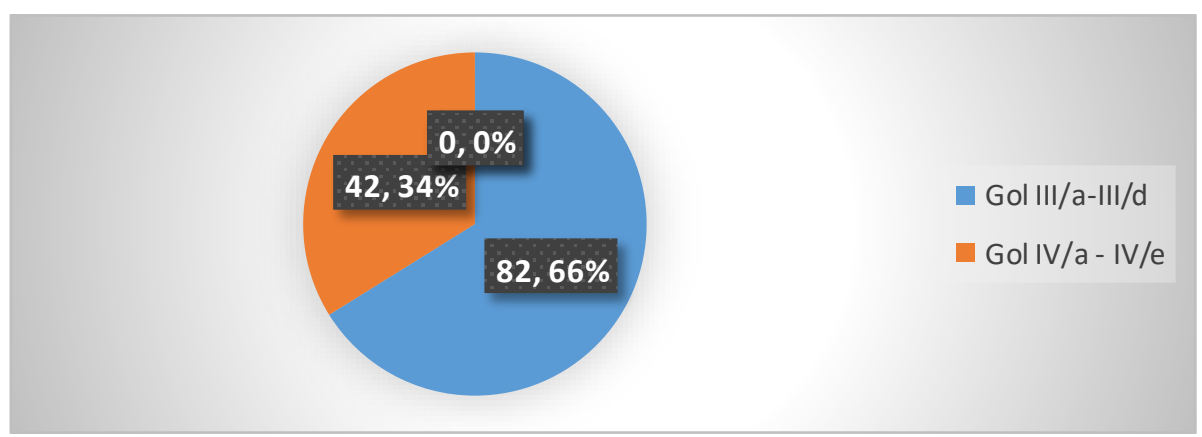

\section{Gambar 4. Golongan Responden}

Terkait dengan pemangkasan anggaran, ASN di pusat/provinsi/kabupaten/kota sudah mengetahui adanya pemangkasan APBN/APBD, baik itu yang telah disampaikan oleh pimpinan, informasi dari ASN lainnya, hingga media massa. Dari data yang ada, sebanyak 66 orang $(53,2 \%)$ menyatakan mereka sangat mengetahui adanya pemangkasan, 57 orang $(46 \%)$ mengetahui pemangkasan dan 1 orang $(0,8 \%)$ menyatakan tidak mengetahui refocusing anggaran.

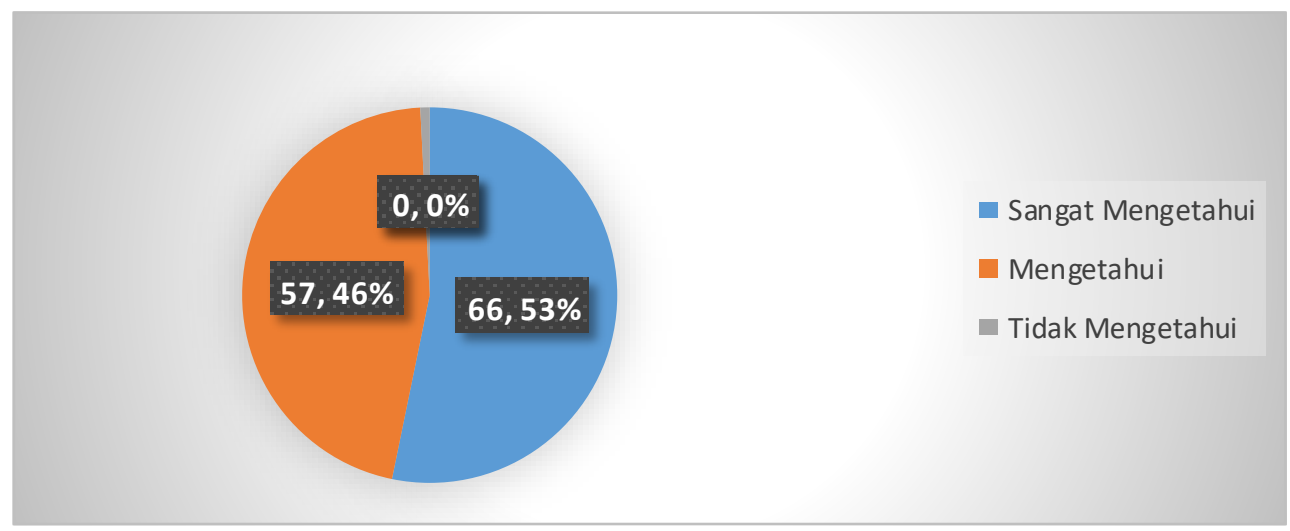

Gambar 5. Informasi Refocusing Anggaran

Seperti yang telah dijelaskan di awal bahwa pemangkasan anggaran dalam mendukung pelaksanaan program dirasakan sangat berpengaruh terhadap program rutin tahunan instansi, baik itu program prioritas nasional maupun program reguler lainnya. Seperti responden menyatakan sangat mempengaruhi sebanyak 69 orang (55,7\%), yang menyatakan mempengaruhi sebanyak 54 orang $(43,5 \%)$ dan yang menyatakan tidak berpengaruh sebanyak 1 orang $(0,8 \%)$.

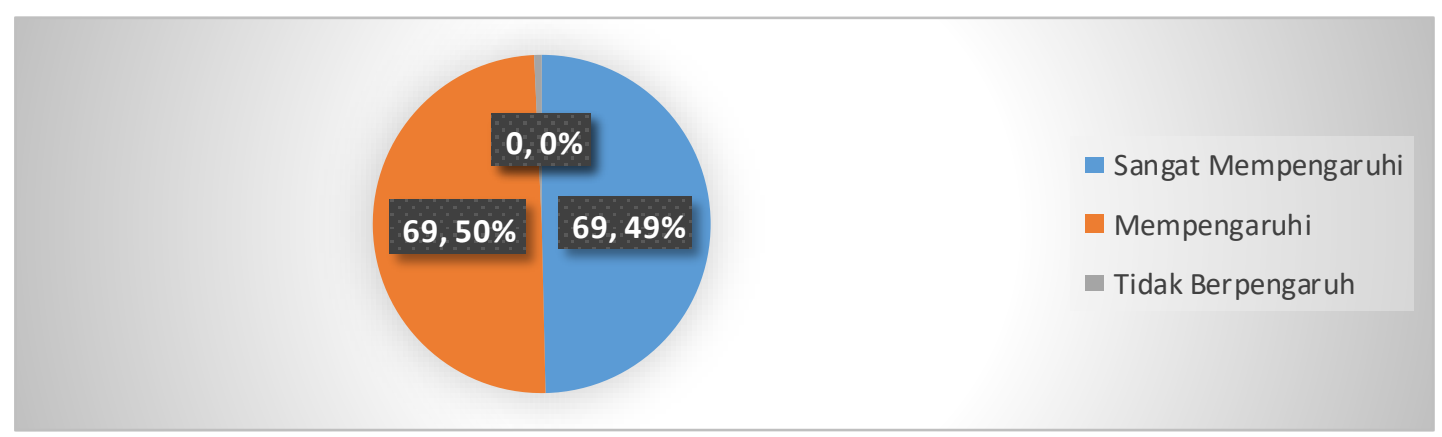

Gambar 6. Pengaruh Refocusing Anggaran Terhadap Program 
Tanggapan responden terhadap pemotongan anggaran sangat beragam, yang menyatakan sangat menyetujui sebanyak 32 orang $(25,8 \%)$ dengan argumen bahwa pemotongan anggaran memang berdasarkan skala kebutuhan besar yang harus ditangani bersama-sama mulai dari pusat sampai daerah melalui refocusing/realokasi belanja daerah. Pada poin memang sudah saatnya kegiatan instansi dilakukan tidak monoton, menyetujui sebanyak 81 orang $(65.3 \%)$ dan tidak menyetujui sebanyak 11 orang $(8,9 \%)$ beragumen bahwa dengan adanya pemotongan, sebagian kegiatan akan mengalami kesulitan untuk direalisasikan khususnya kegiatan riset dan kegiatan yang sifatnya pelayanan kepada masyarakat.

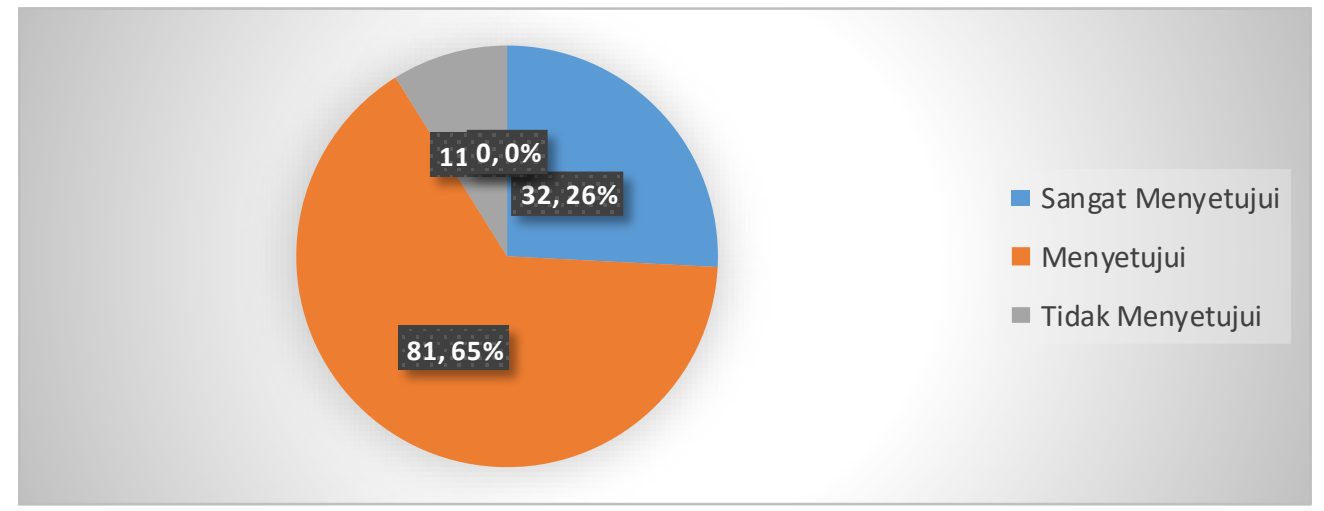

Gambar 7. Persepsi Responden Yang Menyetujui Refocusing

Kinerja ASN, baik di pusat maupun daerah menjadi agenda yang berperan penting dalam menjaga keberlangsungan organisasi. Pengaruh kinerja ASN sangat besar dalam menjaga keberlangsungan sebuah organisasi. Untuk itu responden menyatakan sangat berpengaruh sebanyak 25 orang $(20,2 \%)$ dengan alasan bahwa akan menghambat program kerja dan menghambat kinerja lembaga maupun individu, yang berpendapat berpengaruh sebanyak 62 orang $(50 \%)$ dan yang berpendapat tidak berpengaruh sebanyak 37 orang $(29,8 \%)$ dengan alasan bahwa pemotongan ini merupakan sebuah kewajiban dalam menanggulangi bencana. Apabila ada program yang tidak didanai oleh anggaran dapat dicarikan alternatif kegiatan yang tidak memerlukan biaya seperti kegiatan riset dapat dilakukan tidak mesti turun ke lapangan bisa dengan cara studi literatur, penyebaran data secara online, dan memanfaatkan teknologi lainnya.

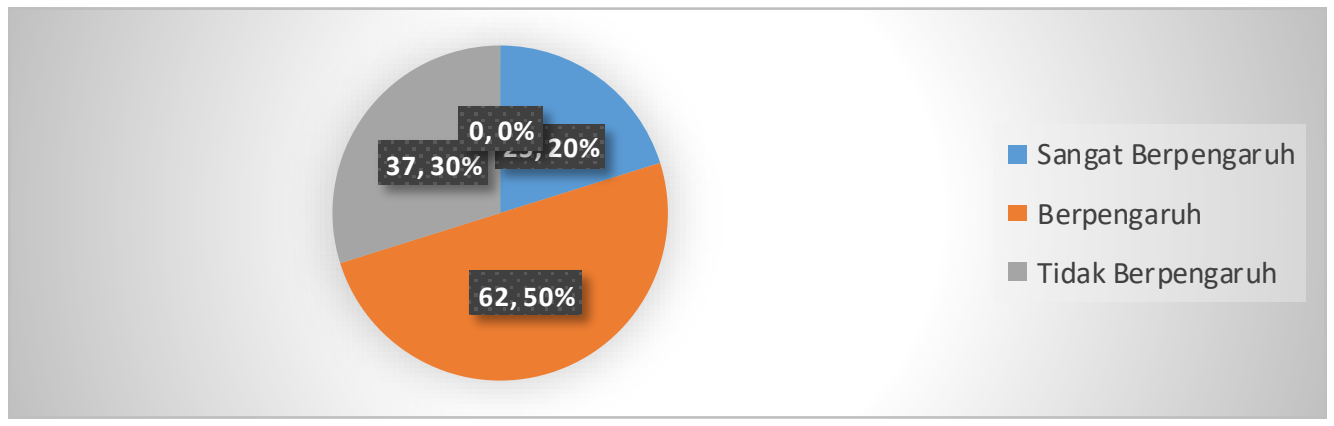

Gambar 8. Refocusing Anggaran Berdampak Pada Kinerja

Selama menjalankan aktivitas bekerjanya ASN juga membuat sebuah perencanaan untuk mengatasi tuntutan kinerja yang maksimal untuk hasil yang optimal. Adapun kebijakan kinerja ASN dalam menghadapi pemangkasan APBN/APBD sebagai berikut.

1. Perencanaan kegiatan meliputi restrukturisasi anggaran belanja dan kegiatan yang bukan prioritas, serta perencanaan agenda kegiatan dengan mempertimbangkan 
efisiensi dan efektivitas dengan menyederhanakan proses kerja. Efisiensi adalah menekankan anggaran seminimal mungkin untuk hasil yang maksimal. Efektivitas berarti sejalan dengan tugas dan fungsi lembaga.

2. Kegiatan riset dapat dialihkan pada aktivitas: (1) Mempublikasikan hasil riset di tahun sebelumnya untuk pencapaian Hasil Kerja Minimal dan Angka Kredit Waktu Tahunan bagi fungsional peneliti; (2) Kolaborasi dengan Jabatan Fungsional Peneliti baik di pusat maupun daerah untuk menciptakan produk riset yang efisien dan efektif; (3) Pemanfaatan teknologi untuk menekan biaya operasional, penggunaan Google Form, partisipasi webinar untuk menjaring data, penggunaan aplikasi Zoom untuk berdiskusi sesuai dengan tantangan memasuki revolusi industri 4.0 yang meliputi pemanfaatan teknologi untuk peningkatan kapasitas agar menjadi digital talent dan digital leader, memperluas jejaring untuk memotivasi pekerjaan, baik di pusat maupun daerah, dan bekerja tidak hanya untuk hari ini, semaksimal mungkin harus lebih baik dari yang dikerjakan sebelumnya.

3. Membuat inovasi kerja dengan sumber daya yang tersedia. Inovasi merupakan terobosan peningkatan kapasitas ASN yang dapat dicapai melalui dua hal. Pertama, berpikir tentang inovasi praktis untuk membentuk corporote culture. Langkah ini dapat mendorong orang untuk melakukan inovasi dengan menciptakan budaya inovasi. Caranya dengan melibatkan seluruh ASN pada setiap kegiatan/program untuk menumbuhkan komitmen dan loyalitas, menciptakan kebersamaan dan membentuk kerja tim yang baik, mendengarkan aspirasi ASN terhadap usulan program/kegiatan tanpa memandang pangkat dan jabatan, sikap keterbukaan instansi agar ASN berkontribusi sesuai dengan kompetensinya, serta memberi award/penghargaan (tidak mesti berbentuk finansial namun bisa berbentuk motivasi) agar ASN bisa bekerja lebih baik. Kedua, membuka kesempatan yang baik meski dukungan anggaran minim dengan memanfaatkan ide kreatif di luar rutinitas. Tujuannya untuk mengeksplorasi kompetensi diri sejauh mana kita dapat memanfaatkan peluang/kekosongan waktu dengan menciptakan produk kerja yang dapat mendukung target kerja lembaga/individu. Ketiga, berpegang prinsip 4B yaitu kerja keras, kerja cerdas, kerja tuntas, dan kerja ikhlas. Dengan demikian hasil kerja ASN akan memiliki nilai yang lebih. Keempat, selalu berpikir positif agar muncul pribadi kreatif. Seperti halnya situasi kerja dengan WFH, ASN dituntut aktif berkomunikasi antara atasan dan bawahan agar kinerja dapat tetap tercapai. Sistem pengawasan bisa menjadi ukuran untuk menilai kualitas ASN. Dengan demikian capaian kinerja yang dilaporkan menjadi indikator tercapainya kinerja ASN dalam menyelesaikan tugas dan fungsinya.

Refocusing anggaran yang diperuntukkan bagi kesejahteraan masyarakat di masa pandemi, menjadi sebuah kesempatan baik bagi ASN untuk pembuktian bahwa kinerjanya dipengaruhi oleh hal-hal lain di luar ketersediaan anggaran. Penyediaan anggaran dapat mempengaruhi sebuah program berjalan namun tidak dapat mempengaruhi kinerja ASN. Terdapat tiga aspek yang mempengaruhi kinerja ASN, yaitu disiplin kerja, motivasi kerja, dan kemampuan SDM. Contohnya di Kabupaten Bulungan, pemerintah daerah telah memberikan tunjangan perbaikan penghasilan yang cukup jika dibandingkan dengan gaji pokok PNS namun hal tersebut belum memperlihatkan pengaruh yang maksimal (Jaenudin 2015) sebab pola kinerja bergantung pada kepribadian ASN yang sesuai standar kompetensinya.

Beberapa keuntungan dan kelemahan terhadap pemangkasan APBN/APBD terdapat pada tabel 1 di bawah ini. 
Tabel 1. Keuntungan dan Kelemahan

Pemangkasan APBN/ APBD terhadap Kinerja ASN

\section{Kebijakan \\ Kinerja ASN \\ Reviu Perencanaan \\ kegiatan}

\section{Revolusi riset}

Inovasi kerja
Keuntungan

1. Target program lebih terukur

2. Perencanaan anggaran dapat efektif dan efisien

3. Pembentukan team work sesuai dengan target kinerja

4. Konsistensi ASN dalam melaksanakan kegiatan sesuai rencana

1. Sesuai dengan perkembangan revolusi 4.0

2. Target program lebih terukur

3. Dedikasi ASN sebagai pelayan masyarakat

4. Membangun network

1. Mengasah kreativitas ASN

2. Meningkatkan kompetensi ASN

3. Membangun komunikasi efektif

4. ASN bekerja di luar rutinitas

Sumber Data: Data diolah, 2020

\author{
Lemahnya pengawasan \\ terhadap capaian kinerja \\ ASN
}

\section{Kelemahan}
1. Kurang dukungan instansi dalam menyediakan sarana prasarana

2. Berkurangnya motivasi ASN untuk melakukan revolusi riset
1. Menciptakan ide sulit, tidak semua ASN mampu memahami kemampuan dirinya dan membaca peluang
2. Masih menggunakan pola lama, bekerja mengandalkan dukungan anggaran

Reformasi birokrasi diarahkan pada upaya melakukan pembaharuan dan perubahan mendasar terhadap sistem penyelenggaraan yang menyangkut aspek kelembagaan, ketatalaksanaan, dan sumber daya manusia aparatur. Dengan kata lain reformasi birokrasi adalah langkah strategis untuk membangun aparatur negara agar lebih berdaya guna dan berhasil guna dalam mengemban tugas umum pemerintahan. Caranya melalui peningkatan kualitas kinerja aparatur yang dicapai, baik itu ASN di pusat maupun daerah.

Pada dasarnya kinerja ASN setiap tahunnya selalu mendapat evaluasi kinerja sesuai dengan UU No 5 tahun 2014 tentang ASN, PP No. 30 Tahun 2019 tentang penilaian kinerja Pegawai Negeri Sipil dan PP No. 46 Tahun 2011 Tentang Penilaian Prestasi Kinerja PNS. Indikator yang dilakukan untuk penilaian kinerja PNS, yaitu hasil kerja yang dicapai pada unit kerja sesuai Sasaran Kinerja Pegawai (SKP) dan Perilaku Kerja. Pada penilaian dilakukan berdasarkan perencanaan kinerja pada tingkat individu dan tingkat unit atau organisasi dengan memperhatikan target, hasil, manfaat yang dicapai, serta perilaku PNS. Kedua aspek penilaian tersebut mutlak dicapai oleh para ASN. Kajian (Yossy 2018) 
menyatakan bahwa SKP diharapkan dapat mengetahui secara tepat keberhasilan pekerjaan. Artinya SKP tidak membutuhkan waktu yang lama dalam melakukan evaluasi pegawai. Terlebih jika setiap tahun diukur maka secara otomatis akan muncul nilai penilaian pegawai berdasarkan objektivitas. Inilah yang menjadi salah satu syarat bagi ASN yang akan menaiki jabatan ataupun pangkat

Akan tetapi di tahun ini tidaklah mudah, ASN dihadapkan pada tantangan untuk meningkatkan kinerja di tengah wabah Covid-19. Tantangan terberat yaitu bekerja maksimal dengan dukungan anggaran yang minim. Keterbatasan anggaran menuntut ASN beradaptasi untuk bekerja sesuai dengan target. Kreativitas dan motivasi merupakan kunci adaptasi. Seperti dikatakan (Effendi 2010) bahwa reformasi perlu ditopang oleh motivasi untuk mencari cara yang lebih efektif dan efisien.

Artinya, kinerja ASN sepatutnya tidak berpengaruh terhadap keterbatasan anggaran. Sebab, kinerja dapat dicapai meski anggaran terbatas. Misalnya, dengan menerapkan pola kerja yang sistematis dan pragmatis atau melakukan riset dengan metode analisa studi literatur secara kompleks.

\section{PENUTUP}

ASN dalam berinovasi menjadi kondisi yang sulit ditawar lagi. Masa pandemi mengharuskan ASN bekerja dengan capaian target lembaga maupun target individu. Hal ini tidak hanya terjadi di kementerian/lembaga di pusat saja, namun juga pemerintah daerah harus mampu menerapkan inovasi sebagai kunci jawaban dalam meningkatkan etos kerja ASN. Dari hasil kajian dapat disimpulkan beberapa hal. Pertama, kinerja ASN dalam menghadapi refocussing anggaran tidak menjadi hambatan bagi ASN untuk meningkatkan kinerjanya. Kedua, ASN menerapkan inovasi untuk meningkatkan kinerjanya seperti menerapkan pola kerja sesuai dengan kompetensinya. Ketiga, ASN memiliki peluang untuk meningkatkan motivasi dan etos kerja dalam rangka peningkatan kinerjanya.

Rekomendasi kajian ini adalah, pertama, mengatur perencanaan kegiatan lembaga tanpa mengenyampingkan pencapaian target kinerja, baik dari kuantitas maupun kualitas. Maknanya, perencanaan ini disesuaikan dengan prioritas kebutuhan lembaga dan kebutuhan ASN. Kedua, membuat pola kerja berdasarkan prinsip riset mandiri dengan sumber daya terbatas dan pemanfaatan teknologi. Cara ini menjadi alternatif memanfaatkan situasi di masa pandemi dan tidak tergantung dengan anggaran. Ketiga, menciptakan motivasi inovasi melalui kerja cerdas, kerja ikhlas, dan kerja tepat, tekun, dan tuntas (3T).

\section{UCAPAN TERIMA KASIH}

Secara pribadi kami berterima kasih kepada Bapak Matheos Tan selaku Kepala Pusat Litbang Inovasi Daerah, Bapak Asrori, dan para responden yang aktif di pusat maupun daerah yang berkontribusi dalam kajian singkat ini. Semoga kajian ini dapat mengubah mindset dan pola kerja yang sudah diterapkan ASN selama ini, serta menjadi motivasi untuk mengembangkan kompetensi dan kualitas kerja. 


\section{DAFTAR PUSTAKA}

Elena, M. (2020, September 22). “Pesan Menkeu: APBN dan APBD Harus Tetap Transparan Selama Penanganan Covid-19." (H. Alaydrus, Penyunt.) Dipetik September 20, 2020, dari Https: / Ekonomi.Bisnis.Com/ Read/20200922/10 / 1294881 /Pesan-MenkeuApbn-Dan-Apbd-Harus-Tetap-Transparan-Selama-Penanganan-Covid-19.

Husain. 2010. Pengaruh Partisipasi Anggaran Terhadap Kinerja Pimpinan dengan Desentralisasi, Budget Goal Commitment dan Job Relevant Information sebagai Variabel Moderating (Studi Empiris Di Pemerintah Kota Ternate)Title. Malang: Universitas Brawijaya.

Jaenudin. 2015. “Faktor-Faktor yang Mempengaruhi Kinerja PNS pada Setda Kabupaten Bulungano." Jurnal Administrasi Negara 21, No.2: 50-61. doi:doi:https"/doi.org/10.33509/jan.v21i2.23.

Jalis, A. 2018. "ASN Harus Kreatif Berinovasi dan Berkontribusi Aktif Pecahkan Masalah di Masa Depan." https://www.bkn.go.id/berita/asn-harus-kreatif-berinovasi-danberkontribusi-aktif-pecahkan-masalah-di-masa-depan.

Kemenkeu. 2020, April 27. "Perubahan Postur dan rincian APBN 2020 di Masa Pandemi Covid 19". Dipetik September 24, 2020, dari http://www.anggaran.kemenkeu.go.id/in/post/perubahan-postur-dan-rincianapbn-2020-di-masa-pandemi-covid-19:

http://www.anggaran.kemenkeu.go.id/in/post/perubahan-postur-dan-rincianapbn-2020-di-masa-pandemi-covid-19

Kian, Tan Shen,Wan Fauziah Wan Yusof. 2015. "Motivation and Promotion Opportunity of Academic Citizen Toward Open Innovation: Proposed Model". Procedia Social and behavioral Sciences, 29-35. Dipetik September 13, 2020, dari https:/ / reader.elsevier.com/reader/sd/pii/S1877042815047540?token=AA409041D1 F50ED3A5A5687AA7D65C67CBEB7875037D556ADD076C8FF84E55585499A4EF509 A5C52BB74769B902FE86F

Lao, H. A. 2018. “Analisis Pengaruh Motivasi Internal dan Motivasi Eksternal Terhadap Kinerja Karyawan Swiss Belin Kristal Kupang." Jurnal Penelitian Manajemen Terapan 3 No.0: 1-10. Dipetik September 18, 2020, dari http://journal.stieken.ac.id/index.php/penataran/article/view/329

Londong, C. 2015. “Faktor-Faktor yang Mempengaruhi Kinerja PNS Kota Manado.” Jurnal Pembangunan Dan Ekonomi Daerah 17, No.2.. doi:https://doi.or/10.35794/jpekd.10251.17.2.2015

Puspasari, R. 2020. "Pemantauan dan Evaluasi Atas Realokasi dan Refocussing APBD Untuk Penanganan Covid-19." Dipetik September 20, 2020, dari https: //www.kemenkeu .go.id/ publikasi/siaran-pers/siaran-pers-pemantauan- dan -evaluasi -atasrealokasi-dan-refocusing-apbd-untuk-penanganan-covid-19-di-daerah/.

Rahsel, Y. 2016, Juli. "Pengaruh Motivasi Kerja Terhadap Kinerja Pegawai Administrasi Pusat Universitas Padjajaran Bandung (Studi pada Bagian Administrasi Umum UNPAD)". Jurnal Manajemen Magister, 02, No 02, 208-220. Dipetik September 19, 2020, dari https://jurnal.darmajaya.ac.id/index.php/jmmd/article/view/902 
Sutrichastini, A. 2015. "Pengaruh Motivasi Kerja Terhadap Kinerja Pegawai Kantor Sekretariat Daerah Kabupaten Gunung Kidul". Jurnal Kajian Bisnis, 23, No.2, 121-137. Dipetik September 4, 2020, dari https://doi.org/10.32477/jkb.v23i2.164 ,http://jurnal.stieww.ac.id/index.php/jkb/article/view/164

Taher, A. P. 2020, Maret 20. "Dampak Corona Jokowi Minta APBN dan APBD Non Prioritas Dipangkas". (B. Septianto, Penyunt.) Dipetik Agustus 1, 2020, dari https:/ / tirto.id/ dampak-corona-jokowi-minta-apbn-dan-apbd-non-prioritasdipangkas-eGpU.

Yanida. 2013. "Pengaruh Partisipasi Anggaran Terhadap Kinerja Aparatur Pemerintah." Jurnal Akutansi Multiparadigma 4, No.3: 330. Diambil kembali dari download.garuda.ristekdikti.go.id 